\title{
Din Eğitimi ve Bireysel Otonomi: Felsefî̀ Perspektif
}

\author{
VEFA TASDELEN
}

“Tanrı'ya karşı en büyük hakaret, onu hiç düşünmemek değil, onun hakkında kötü düşünmek olurdu."

Rousseau

\section{Özet}

İnsanın ilk ve en temel faaliyet alanlarından birisi olan eğitim, bilgi, tecrübe ve değer aktarımı olarak, modern zamanlara doğru gelindiğinde bilimsel, felsefî ve sistematik bir nitelik kazanmıştır. İnsan, kendi tecrübe ve birikimini gelecek kuşaklara, onların yararına olacak şekilde aktarmak istemiştir. Yeni nesiller bu eğitimle hayata daha sıkı tutunup daha iyi adapte olabilecekler, sosyal ve fiziksel çevreye en iyi şekilde uyum sağlayabilecekler, yeryüzünde insan olmanın anlam ve değerini daha derinden hissedebileceklerdir.

İşte bu eğitim biçimlerinden biri de din eğitimdir. İbn Haldun ve Giambattista Vico'nun medeniyet ve sosyal bilimler teorisi bağlamında işaret ettikleri üzere insan ilahi bir inayet olmak üzere bizzat Tanrı tarafından eğitilmiş, bir arada yaşamanın kural ve ölçütleri kendisine verilmiştir. Buna göre Rab, insanlığın ilk ve en esas terbiye edicisidir.

Bu makalede din eğitimi, (1) "dinî akidelerin eğitimi”, (2) "din kültürü eğitimi" olmak üzere iki şekilde ele alınacaktır. Dinî akidelerin eğitimi, belirli bir dinin

-GÖRÜS-

Çocuk ve Medeniyet
VEFA TASDELEN, vefatasdelen1@gmail.com

Yıldız Teknik Üniversitesi Eğitim Fakültesi Eğitim Bilimleri Bölümü

ORCiD https://orcid.org/0000-0003-3937-3413

doi: https://doi.org/10.47646/CMD.2021.259 
inanç ilkeleri etrafında, o dinin içeriğinin kazandırılmasına yönelik verilir. Din kültürü eğitimi ise dinin ve inancın doğasını, felsefî ve bilimsel bir çerçevede ele alan bir eğitim olacaktır. Bu eğitime ilişkin bir ders, insanın yeryüzündeki ruhsal evrimine ışı tutan bir ders olmak üzere, diğer kültür dersleri gibi seçmeli veya zorunlu olarak okutulabilir. Dinî akidelerin eğitimi ise belirli bir dinin inanç ve yaşam ilkelerini öğreten bir ders olarak bireyin (öğrenci ve ailesi) tercihine bırakılması anlamlı olacaktır. Bu durum, dinlerin temelinde olan tolerans ve insan iradesine saygı anlayışına da uygun düşecektir. Bununla birlikte din eğitimi, bir bütün olarak devletin resmi kurumlarında verilecek bir saatlik süreyle sınırlanamayacak denli geniş boyutları olan, neredeyse baştan sona insan hayatının tümünü kuşatan bir derstir. Bu eğitim çok küçük yaşlarda ailede başlar ve bir şekilde ömür boyu sürüp gider.

Anahtar kelimeler: Eğitim, felsefe, din eğitimi, dinî akidelerin eğitimi, din kültürü eğitimi, tanrı tasavvuru, bireysel otonomi.

\begin{abstract}
Education, which is one of the first and most basic fields of activity of human beings, has gained a scientific, philosophical and systematic quality when it comes to modern times, as the transfer of knowledge, experience and value. Man wanted to transfer his own experience and knowledge to future generations in a way that would benefit them. With this education, new generations will be able to hold on to life more tightly and adapt better, adapt to the social and physical environment in the best way, and feel the meaning and value of being human on earth more deeply.
\end{abstract}

One of these forms of education is religious education. As Ibn Khaldun and Giambattista Vico pointed out in the context of civilization and social sciences theory, man was personally trained by God as a divine grace, and the rules and criteria of living together were given to him. Accordingly, God is humanity's first and most essential trainer.

In this article, religious education will be discussed in two ways: (1) "education of religious creeds" and (2) "religious culture education". The education of religious creeds is given around the belief principles of a particular religion, in order to gain the content of that religion. Religious culture education, on the other hand, will be an education that deals with the nature of religion and belief in a philosophical and scientific framework. A course related to this education can be taught as an elective or compulsory course, like other culture courses, as a course that sheds light on the spiritual evolution of man on earth. It would be meaningful to leave the education of religious creeds to the preference of the individual (student and his/her family) as a course that teaches the beliefs and life principles of a particular religion. This will also be in line with the 
understanding of tolerance and respect for human will, which is the basis of religions. However, religious education as a whole is a lesson that encompasses almost the whole of human life, with dimensions too wide to be limited to the one-hour period to be given in official institutions of the state. This education starts in the family at a very young age and continues for a lifetime.

Keywords: Education, philosophy, religious education, education of religious creeds, education of religious culture, imagination of god, individual autonomy.

\section{Giriş}

Kınalızâde Ali, Ahlâk-ı Alâ̂̀'de Immanuel Kant'ın Eğitim Üzerine (Über Pädagogik)'te ortaya koyduğu anlayışı önceleyecek şekilde insanın eğitimle insan olabileceği, insan olma hasletini geliştirebileceği hususunu "hurma çekirdeği metaforu" ile etkili bir şekilde dile getirir: "Hurma çekirdeği; ne elma, ne de hurma ağacıdır. Ancak öyle bir şekilde yaratılmıştır ki, terbiye edilmesi durumunda hurma ağacı olması mümkündür. Ve kendi kendine olmayıp bu kabiliyet ancak terbiye ile gelişir. (Kınalızâde, t.y., s. 39). Buna göre insan çekirdektir; nasıl bir insan olacağı, alacağı eğitime bağlıdır.

Filozof ve eğitimcilerin üzerinde durageldikleri üzere insan doğuştan sadece fiziksel anlamda güçsüz ve yetersiz olarak doğmaz, aynı zamanda pek çok insanî hasletin geliştirilmesine ihtiyaç duyacak şekilde de doğar. $\mathrm{O}$, bu hasletlerin potansiyeline sahiptir, ancak onların eğitim yoluyla geliştirilmeleri de gerekir. İnsanın, en uzun süreli bakıma muhtaç bir varlık olduğu, tabiatta onun kadar anne babasının bakım ve ihtimamına ihtiyaç duyan başka bir varlık olmadığı bilinir. Bu ihtiyacı yalnız fiziksel gereksinimlerle sınırlamak yanlış olur; o, duygusal, zihinsel, sosyal anlamda olgunlaşmaya da ihtiyaç duyar. Gazâlî doğuştaki bu eksikliği fiziksel yapı ve benlik (nefs)'teki eksiklik olarak iki şekilde ele alır: Nasıl ki insanoğlu doğarken bedeni, vücudu tam ve mükemmel olarak doğmaz, aldığı gıdalarla yavaş yavaş büyüyüp gelişirse, bunun gibi nefsi/benliği de doğarken yarım ve gelişmeye müsait olarak doğar; zamanla aldığı terbiye, eğitim ve öğretime paralel olarak gelişir, olgunlaşır, kemâle erer (Gazâlî, 1996, s. 77). Gazâlî, yine insanın iyilik ve erdem yolunda gelişebilmesi için eğitime olan ihtiyacını şu şekilde vurgular: "Bil ki, çocukların eğitimi en önemli ve öncelikli işlerdendir. Çocuk, anne ve babasının yanında korunması gereken bir emanettir; onun kalbi sade, temiz ve parlaktır; ona iyi şeyler öğretilirse bunları kabul eder ve huy hâline getirir, kötü şeyler verilirse onları alır ve onlarla yaşar. Bu sebeple iyi, doğru ve güzel şeyler öğretilerek onu bir melek hâline getirmek de, kötü ve yanlış şeyler vermek veya kendi hâline bırakıp 
ihmâl etmek suretiyle onu şeytan veya hayvan durumuna getirmek de mümkündür" (Gazâlî, 2021, s. 1620).

Eğitim, insan olma potansiyelimizi geliştiren, bizi olgunlaştıran en temel faaliyet alanıdır. İnsanın olduğu her yerde eğitim öğretim faaliyeti de olmuştur. İnsan bilgi ve varoluş tecrübesini gelecek kuşaklara eğitimle aktarmış, yeryüzündeki fiziksel ve manevi varlığını eğitimle desteklemiştir. Modern zamanlara doğru gelindikçe insanın kendisi, çevresi, toplumu ve diğer varlıklarla olan ilişkisi oldukça karmaşıklaşmış, bilgi, teknoloji ve meslek alanları geliştikçe sistematik ve programlı bir şekilde eğitim ihtiyacı ortaya çıkmış, bunun bir sonucu olarak eğitim felsefí, bilimsel ve akademik bir faaliyet alanı hâline gelmiştir. Buna göre her eğitim-öğretim faaliyeti belirli bir program dâhilinde gerçekleşir. Programın bir içeriği, akışı, hedef davranış ve kazanımları vardır. Çok yönlü yapısıyla program, içeriğin oluşmasından amaçların belirlenmesine, öğretilen bilginin doğasının sorgulanmasından ölçme ve değerlendirme sürecine kadar felsefî bir nitelik taşır.

Bu çerçevede bakıldığında din eğitimi diğer eğitim biçimlerinin yanında önemli bir konumda bulunur. Onun da kendine göre bir içeriği, kaynakları, araştırma ve sorgulama yöntemleri vardır. Bu konuda şu soruları sorabiliriz: Din eğitiminin insan varoluşundaki, insanın maddi ve ruhsal dünyasındaki yeri nedir? Din eğitimi hangi bilginin üzerinde temellenir ve ne tür bir bilginin taşıyıcılığını yapar? Yalnız belirli bir tür bilginin taşıyıcılığını mı yapar, yoksa daha ileri bir tecrübeyi, bilginin öznel bir deneyime evrilmesini mi amaçlar? Nasıl bir insan ve toplum modeli ortaya koyar, hedef davranışları nelerdir? Belirli bir inancın ilkeleri ve ibadet tarzını mı öğretir, yoksa inancın insan doğasındaki yerini ve anlamını mı sorgular? Makalede bu ve benzeri sorular, (1) "dinî akidelerin eğitimi", (2) "din kültürü eğitimi" olmak üzere iki şekilde ele alınacaktır. Bir din eğitimi her iki şekilde de verilebilir ya da her ikisinin sentezinden bir üçüncü yol oluşturulabilir. Buna göre din kültürü eğitiminin doğası, Tanrı tasavvuru, birey Tanrı ilişkisi gibi konular çerçevesinde felsefî ve evrensel bir nitelikte ortaya çıkarken, belirli bir dinin akidelerinin ele alındığı ve öğretildiği din eğitimi ise yerel ve kültüre düzeyde kendini gösterir.

\section{1. İki Yaklaşım}

Din eğitimi bizdeki dini ve dindarlığı oluşturan bir eğitimdir. Bizdeki Tanrı, bizdeki din, bizim inancımızdır. Tanrı nasıl bizim Tanrı'mız, din nasıl bizim dinimiz olmuştur; bu soruyu herkes kendi tecrübesine dayanarak cevap arayabilir. Hemen ilk planda aklımıza geldiği üzere, din eğitimi aileden, 
sosyal çevreden alınan etkilerle başlar ve şekillenir. Kültür ve sosyal çevre, kendi inancını belli belirsiz gelecek kuşaklara aktarır. Tıpkı başka konularda olduğu gibi içine doğduğumuz kültüre, onun değerlerine tabi oluruz. Bu, yalnız bir-iki kültür için değil, bütün din ve inanışlar için böyledir. Din eğitiminde bir toplum ve kültür içine doğmuş olmak, aldığımız eğitimin ilk ve en önemli aşamasını oluşturur. Bundan sonrası kültürel mirası almak ve özümsemek şeklinde kendini gösterir. Bu "tâbî olma" durumu, genellikle bizim istemimizin dışında geçekleştiğinden bir tercih ve irade beyanı söz konusu değildir. Toplum belirli bir inanış çerçevesinde bireyi yönlendirir, motive eder, koşullar. Bu, çoğu kez bireyin seçimi, tercihi, beğenisi, dünya görüşü çerçevesinde ortaya çıkmaz; başka deyişle içinde bulunduğumuz toplumun dinî inanışlarını benimseriz; dünyanın hangi inanç ve kültür coğrafyasında bulunursak, genel anlamda örnekleri hep gördüğü üzere biz de çok büyük ihtimalle o inanç bölgesinin değer yargılarını ve davranış tarzlarını benimseyerek büyürüz. Bu durumda kolaylıkla tahmin edileceği gibi din eğitimi bireyin dinleri tanıma ve belirli bir dini seçme konusunda aldığı eğitim olmaktan ziyade, sosyal çevrede geçerli olan inanışın bireye aktarımı şeklinde gerçekleşir. Dini ve inancı en çok sorgulayan filozofların bile bu adet üzere oldukları düşünülürse, söz konusu çevrenin birey üzerindeki belirleyici etkisi kendiliğinden ortaya çıkar. Bu bir bakıma "tanrısal inayet”, bir bakıma literatürdeki "taklidi iman”a karşılık gelir.

Din eğitiminin konusu olan dinî bilgi, vahiy bilgisi ve din kültürünün ürettiği bilgi olmak üzere iki kaynağa sahiptir. Vahiy, inancın doğaüstü bilgi kaynağı, Tanrı'nın insana, bizzat bireye seslenişidir. Kutsal mesaj, öncelikle bir kitleye gelmez, tek tek bireylere gelir. Onun muhatabı birey, bireyin kendisidir. Anlamak, özümsemek ve karar vermek durumunda olan bu bireydir. Bu hitapla birey Tanrı'nın muhatabı hâline gelir. Bu nedenle kutsal mesaj, bir topluma, bir çağa değil, öncelikle nerede olursa olsun ve hangi zaman diliminde yaşarsa yaşasın tek tek her bir bireye hitap eder. Her bir bireye, bireyin kendi idrak sınırları ve varoluş koşulları içinde hitap eder. Din eğitiminde kutsal kaynaklarla, bu iletişim kanalının, bu varoluşal bağlanmanın oluşturulması durumu söz konusudur. Bu da bir dinî tecrübe üzerinden oluşur ya da bizzat dinî tecrübenin kendisini oluşturur.

Din eğitimi yukarıdaki iki yaklaşım çerçevesinde, yerine ve bakış açısına göre ilki, yerine ve bakış açısına göre ise ikincisi veya her ikisinin sentezinden oluşan bir üçüncü yol olarak öne çıkararak bireyde dinî tecrübe oluşturmayı amaçlayan bir eğitimdir. Bu tecrübe ne üzerinden oluşturulacaktır: salt kurallar, cezalar, yasaklar ve korkular üzerinden mi, yoksa sevgi ve varoluşsal bağlanma üzerinden mi? Bireyin Tanrı ile olan ilişkisi, öncelikle fikhi çerçevede ortaya çıkmaz. Fıkhi çerçeve bireyin Tanrı 
ile ilişkisinin bir sonucudur. Neyin kural neyin kural olmadığını öğretmek din eğitimi içinde öncelikli değildir; bundan önce daha temel bir ilke yer alır: Tanrı ile aramdaki bağın doğası nedir? Bu bağı nasıl kurabilirim? Tanrı'nın varoluşumdaki yeri nedir? Tanrısız yaşayabilir miyim? Tanrısız neye iyi, neye kötü diyebilirim; böyle bir hayatın anlamı olabilir mi? Dinin vaat ettiği umudun yeryüzündeki varlığım açısından taşıdığı değer nedir? Bütün bu sorular çerçevesinde bakıldığında din eğitimi hayatın anlamını kuran, değer duygusunu, varlığa, evrene ve insana bakışı oluşturan temel bir eğitim olacaktır? Sorun, bu zor, soyut ve felsefî konuların çocuğa nasıl, ne şekilde ve ne kadar verilebileceğidir. Başka deyişle Tanrı nasıl benim Tanrım, din nasıl benim dinim olacaktır?

\section{Merak ve Bilme İsteği}

Çocuğun din eğitimi, esas olarak ona dışarıdan yüklenen bir eğitim değildir; bu eğitime [dışarıdan gelen eğitime] zemin ve gerekçe oluşturacak şekilde aslında onun kendi doğasından çıkan bir eğitimdir. Zira o Tanrı, evrenin oluşumu, hayat ve ölüm gibi konulara merak ve ilgi duyan bir kişi olarak kendi insan doğasından kaynaklanan felsefî ve pratik nitelikli (nedir ve nasıl diye başlayan) soruları vardır. Bu sorular onun kendini, dünyayı ve hayatı anlama sürecinin bir parçasıdır: Kimdir, nedir, neden buradadır, neden bu zaman diliminde yaşamaktadır, doğum ve ölüm nedir, bütün bu olup bitenlerin anlamı nedir? Doğumdan önce bir hayatı var mıydı, ölümle birlikte ne olacaktır? İster istemez bu sorular vardır. Aklın Tanrı, ruh ve evren [evrenin başı ve sonu, ilk ve nihai nedenler] konularında kaçınamayacağı soruları vardır. Dostoyevski iyi ve kötü değerleri konusunda bir inanç bağlamı oluşturur: Tanrı olmadan iyi ve kötü değerleri olabilir mi, ahlâk olabilir mi? Tanrı olmadan yaşam olabilir mi? Sevgi olabilir mi, barış olabilir mi? Ona göre, "Akıl hiçbir zaman iyilik ile kötülük arasındaki farkı görebilecek, hatta yaklaşık olarak iyilik ile kötülüğü birbirinden ayırabilecek güce ulaşmamıştır. Tersine utanılacak derecede birbirine karıştırmıştır ikisini (Dostoyevski, 1984, s. 286-287).

Sorular çoğaltılabilir. Bunlardan bazıları çocuğun kafasında da vardır: Dünya niçin böyledir? İnsan kimdir? İnsan niçin böyledir, niçin buradadır, niçin var olmuştur? Niçin doğmuştur, niçin ölecektir? Sonlu ve sınırlı bir hayatın anlamı ne olabilir? Tanrı'nın yarattığı ve yönettiği evrende kötülük, haksızlık ve adaletsizlik ne olacak, nasıl açıklanacaktır? Bütün bu sorular dikkate alındığında din eğitimi, varlık ve yokluk, oluş ve yaratılış, iyilik ve kötülük, hak ve haksızlık, özgürlük ve zorunluluk/kader kavramları çerçevesinde temelini ve gerekçesini çocuğun doğasında bulan bir eğitim 
olacaktır. Descartes sonlu aklımızın sonsuz bir Tanrı inancını kendiliğinden düşünemeyeceğini söyler (Descartes 1997, s. 161). Ona göre Tanrı fikri bizde doğuştan (idea innata) vardır. Kant, Tanrı fikrinin sosyal çevre ve bireyin kendi içindeki kaynağına işaret eder; böyle bir tecrübe ile kişide Yüce Varlık karşısında saygı, ibadet etme, sığınma isteği oluşur. Ancak o ilk işaretlerini Hayy İbn Yakzan'da bulduğumuz, daha sonra Rousseau'da da karşılaştığımız şu görüşü öne çıkarır: Çocuk, sosyal çevreden Tanrı ile ilgili hiçbir fikir elde etmese bile kendi bilinci onu hayatın normal akışı içinde Yüce Varlık fikriyle karşı karşıya getirir.

\section{Tanri Tasavvuru}

Din eğitiminin temeli bir Tanrı tasavvuruna dayanır. Bu tasavvur kendiliğinden oluşur veya oluşturulur. Tanrı tasavvuru, evrenin ve hayatın, iyinin ve kötünün kökeni, doğum ve ölümle ilgili soruların doğal bir sonucu olarak ortaya çıkar (Kant, 1908, s. 212, Russell, 1999, s. 83). Bu merak kişiyi her şeyin kaynağına koyabileceği bir Tanrı tasavvuru ile karşılaştırır. Nasıl bir Tanrı’ya inanıyorum sorusunun cevap bulması, din eğitimi açısından önem taşır. Bu sorunun cevaplanması önemli olduğu kadar zordur da. Din eğitiminin öncelikle bir felsefe sorunu olarak ortaya çıkması bu zorluk içinde gerçekleşir. Şu sorular da bu zorluğa dâhildir: Dünyevî dil O'nu ne kadar ifade edebilir? Fiziksel dil, metafizik olanı ne ölçüde karşılayabilir? Kullandığımız bütün diller, dünya tecrübemizin ve dünya ile ilişkimizin ürünüdür, dünyaya ait dildir. Tanrı'yı kavrayabilmenin önündeki en büyük engel, dünyaya ait sınırlı bir dille Tanrı'yı düşünüyor, dahası düşünemiyor oluşumdur. Bu dil üzerinden metafizik bir tecrübe oluşturmaya çalışmak, hassas bir konudur. İnsan burada bütün dikkatini kuşanmalıdır. Başlıca ödev, pedagojik bir din dilinin oluşturulabilmesidir. Özensiz bir konuşma, olumsuz bir Tanrı tasavvuru, hassas duyguları tırpanlayacaktır. Dünyevi dil, pedagojik yaklaşımlardan yoksun kalırsa, hoşgörüsüzlüğe, nezaketsizliğe ve kabalığa dönüşebilecektir.

Felsefî açıdan bakıldığında din eğitimin anlamı belirli bir dine ait akidelerin öğretilmesinden ziyade birey ve Tanrı arasında, hayata değer ve anlam katabilecek bir ilişki oluşturabilmektir. Bu tasavvurun oluşmasında vahyin ve dinî tecrübenin temel bir yeri vardır. Vahiy, dünyevî dille bizimle konuşur. Bu nedenle bireydeki Tanrı tasavvuru bu dil üzerinden gerçekleşir ve bireyin din tecrübesini oluşturur. Onu nasıl düşünmeliyim, hangi sıfatlarla düşünmeliyim? Dünyevi dille atfettiğim sıfatlar manevi âlemde ne anlama gelir, onun gerçekliğini ne ölçüde karşılar? Onunla nasıl iletişim kurmalıyım, onunla nasıl temasa geçmeliyim? Din eğitimi, bu sorunların 
cevabını arar. Ve başka temel soruların: Nasıl bir insan olmalıyım, hangi değerlere bağlanmalıyım, nelere yönelip nelerden yüz çevirmeliyim? Hayatımın ve ölümümün anlamı ne olmalı?

Bu sorgulamalardan şöyle bir sonuç ortaya çıkıyor: Tanrı'yı anlatmak ve öğretmek değil, O’nun anlatılamaz ve öğretilemez olduğunu öğretmek din eğitiminin anlamına uygundur. Tanrı'yı bir bilimin veya bir düşüuncenin konusu olarak kavrayabilseydik, o zaman O bizim tasavvurumuzda tanrılık vasfını yitirmiş, Pascal'ın dediği gibi aklımızın kavrama sınırları içinde sıradan bir nesne, ya da Kierkegaad'un dediği gibi bir "kavram" hâline gelirdi. Augustinus ve Jaspes O’nun “kuşatılamazlığı” üzerinde dururken insan aklının kavrayış sınırlarına da işaret etmişlerdir (Augustinus, 1996, s. 152, Jaspers, 1986, s. 58). Onunla iletişim kurmak, onu anlamaya çalışmak, kavranılamazlığı içinde kavramak, bilinemezliği içinde bilmektir. Tanrı'yı her bir durumda belirli bir bilgi, düşünce ve kavram olarak bulmaya çalışmak yerine varoluşu besleyen, destekleyen mutlak adalet, sevgi ve umut olarak anlamak, din eğitiminin amacina uygun düşecektir.

İbn Sina, Hayy İbn Yakzan hikâyesinde, genel anlamda İslam kültüründe geçtiği üzere, Tanrı'nın kavranılamazlığı ve bilinemezliği üzerinde durur: "Onu belli bir asla yakıştıran [Ona belli bir biçim ve suret veren] yoldan çıkmıştır. Onu kendine yakışır şekilde överim diyen hezeyan söylemiş, onun sıfatlarını vasfetme gücünden uzaklaşmış ve O'nu bir şeye benzeterek ölmüştür. Hiç kimse onu bir şeye benzetebilmeye güç yetiremez. Onun parça buçuk uzuvları yoktur. Bütün güzellikler O’nun yüzünün ve elinin cömertliğidir. O'nun güzelliği bütün güzellikleri artırır. O'nun keremi bütün keremleri değersiz kılar. İçlerinden birisi ne zaman yaygısının çevresinde bulunsa, onu iyiden iyiye düşünmek istese hayretten gözleri açılır da oradan şaşkınlık içinde geri döner. [...] Sanırsın ki, O'nun güzelliği kendi güzelliğinin perdesidir, ortaya çıkışı saklanışının sebebidir, zuhur edişi gizlenişinin nedenidir. O'nun 1şı̆̆ı kendi ışı̆̆ının perdesidir. [...] O’nu göremeyenler kendi güçlerinin azlığından göremezler. $O$, iyilik ve ihsan edicidir. O’nun güzelliğinden bir eser gören herkes hep ona bakar, asla gözünü ondan alamaz" (İbn Sina, 1997, s. 66).

Din eğitiminin kökeni felsefî açıdan Platon'a dayandırılabilir. O mitosların Tanrıları yanlış bir tanrı tasavvuruyla kötü ve ahlâksız olarak anlattıkları gerekçesiyle çocuklara anlatılmasını ve okutulmalarını istemez; hatta Homeros'un şiirlerinin yasaklanmasını ister (Platon, Devlet, 1992, s. 67-

Çocuk ve Medeniyet 2021/2
68). Rousseau, onun bu anlayışını sürdürecek şekilde Plutark'ın bir sözünü anımsatır: "Tanrı hakkında aşağılık, fantastik, hakaret dolu, ona layık olmayan fikirlere sahip olmak yerine hiçbir fikre sahip olmamak daha iyidir; 
ona hakaret etmektense onu tanımamak daha az bir kötülüktür.

O iyi yürekli Plutark şunu söyler: "Benim hakkımda, Plutark adaletsiz, haset, kıskanç ve o kadar zorba biridir ki olmayacak şeyi ister, denilmesindense, dünyada Plutarkhos diye biri yoktur, denilmesini yeğlerim" (Rousseau, 2009, s. 192). Rousseau, Plutark'ın bu sözünü tamamlayacak şekilde Emile'nin bir başka yerinde de şunları söyler: "Yetersizliğime iyice inandığımdan, benimle olan ilişkileri dolayısıyla düşünmek zorunda kalmam dışında, Tanrı'nın niteliği üzerine asla düşünmeyeceğim. Bu düşünceler her zaman pervasızcadır. Aklı başında bir insan bu işe ancak ürpererek ve bunları derinleştirmek için yaratılmamış olduğundan emin olarak girişmelidir: Çünkü Tanrı'ya karşı en büyük hakaret, onu hiç düşünmemek değil, onun hakkında kötü düşünmek" olurdu (Rousseau, 2014, s. 386).

İmanda gaib'e (Bakara, 3), Kant'ın deyişi ile numeon'a, "bilinemeyen"e inanmak durumu söz konusudur. Anlama yetimizin konusu, fenomen'dir; onu görürüz, işitiriz, tadarız, koklarız; o, duyularımızın sınırı içinde yer alır. Burada Tanrı'yı, Tanrı'nın kendisinden bahsettiği kadar bilme ve inanma durumu söz konusu olur. Tanrı bir obje hâline getirilemeyen, duyularımızın karşısına çıkarılamayan, kendi irade ve bilgisiyle kuşatan, ama kuşatılamayandır. Onun gaib olması, ancak bir inanç çerçevesinde bilinebileceği yönündedir. Din bilgisi bir yönüyle gaib'in, bir yönüyle gaib'e dayalı din kültürünün bilgisi olacaktır.

Felsefî ve pedagojik açıdan bakıldığında "iyi Tanrı tasavvuru" din eğitiminin en önemli hedefidir. Tanrı'yı şiddetin, öfkenin, gazabın, hoşgörüsüzlüğün, insanların şahsında tanıdığımız bu sıfatların öznesi hâline getirmek, daha çok zaman içinde ortaya çıkan din kültürünün bir eseri olmalı. Tanrı, bütün bu dünyasal tanım ve sıfatların ötesinde, hayatı, hayatın kendi gerçekliğinin üstünde ve ona bir müdahale olarak, bizim içimizde iyilik ve sevgi ile inşa eden bir varlıktır. Kant bunu "baba" metaforuyla anlaşılır hâle getirmeye çalışır: "Tanrı fikrini açık hâle getirmenin en güzel yolu Tanrı'yı kendi ihtimamı altında yaşadığımız bir babaya benzetmektir (Kant, 1908, s. 213-215). Tanrı hakkında, ancak onun rahmetini, iyiliğini, bağışlayıcılığını düşündüğümüzde olumlu bir tasavvura sahip olabiliriz. İnanırken şöyle bir duygu vardır içimizde: İnandığım Tanrı kötü, güçsüz ve aciz bir Tanrı değildir. Merhametsiz ve acımasız bir Tanrı değildir. Beni dünyaya getiren, bana hayat veren, beni varlığa katan ve yine şu anda tam olarak kavrayamadığım bir şekilde beni yine kendisine döndürüp sonsuzluk verecek olan bir Tanrı'dır. Ondan geldim, ona döneceğim. O benim vatanımdır, yurdumdur. Onu tüm nimetlerin, iyilik ve güzelliklerin kaynağı olarak severim. Onu kötü ve kötülük isteyen bir varlık olarak 
düşünmem, düşünemem. "Ceza vericilik" durumu bile, iyilik ve adaletin tecellisine yönelik bir gözeticiliktir. $O$ hayatın, nimetin, güzelliğin, iyilik ve adaletin kaynağıdır. "Tanrı adaletlidir; bundan eminim; bu onun iyiliğinin bir sonucudur. İnsanların adaletsizliği kendilerinin işidir, yoksa Tanrı'nın değil. Filozofların gözünde Tanrı aleyhinde kanıt olan ahlaksal düzensizlik, benim gözümde yalnızca Tanrı'yı kanıtlıyor. Ama insanların adaleti, herkese kendisine ait olan şeyi geri vermekte, Tanrı'nın adaleti ise herkesten, ona vermiş olduğu şeyin hesabını sormakta toplanır" (Rousseau, 2014, s. 399). İnancın temelinde Yaratıcı Kudretin varlığı sevgi, iyilik, güzellik ve adalet üzere yarattığı, hayatın bu değerler üzerine kaim olduğu inancı bulunur. İnanç, insan ruhunda bu iyilik ve güzellik duygusuyla tecelli eder. Bunun hayattaki yansıması sevgidir. En doğru tasavvur Tanrı'yı, sevgi, umut, iyilik ve adalet olarak düşünmektir. Tanrı iyidir. O’nun iyiliği, bütün varlığa, var olan her şeye yayılmıştır. Onun tarafından sevildiğimi, gözetildiğimi ve korunduğumu hissederim. Beni yokluktan çıkarıp düşünmüş ve yaratmış olması, dahası bani sonsuzluğa katacak olması benim için sonsuz bir iyilik ve umuttur. Dünyamın onun tarafından korunduğuna ve gözetildiğine inanırım. Onun kudretine güvenirim. Ona dua ederim. Dualarımla onunla aramda bağ kurarım. Din eğitimi bize Tanrı ile konuşmayı, ona dua etmeyi, bu şekilde Tanrı huzurunda, Varlık önünde bulunmayı öğretir. "Ben sizin zannınız üzereyim" hadisi bile kendi başına umutlu olmam ve Tanrı'yı en iyi şekilde tasavvur etmem için yeterli nedeni sunmaktadır.

\section{Din Eğitimi Ne Olmalı, Ne Olmamalı?}

Neye inanıyorum, nasıl bir Tanrı'ya inanıyorum sorusu yanında nasıl inanıyorum, nasıl inanmalıyım, sorusu da din eğitiminin bir parçasını oluşturur. Aşağıda nasıl inanmalı, nasıl inanmamalıyım, sorularına din eğitimi açısından cevap aranacaktır.

\subsection{Teslim Alma! Teslim Olma!}

Din eğitiminde sık sık üzerinde durulan konulardan biri inanmanın bir "teslim olma" durumu olduğu hususudur. Dinin tanımında her ne kadar "teslim olma" varsa da bu teslimiyet durumu aslinda "asla teslim olma!" diye başlar. Telim olmaya alıştırılan bir millet, iyi yetişmiş, karakterli ve kendine malik bir millet olmayacaktır. İnanma bizden teslim olmayı

Çocuk ve Medeniyet 2021/2 değil, hemen her durumda teslim olmamayı, direnç göstermeyi ve bilinçli olmayı ister. Bu direnç daha çok yine din adına ortaya çıkabilecek istismar, aldatılma, atalet, cehalet karşısında gösterilir. 
“Teslim olmama” konusunda eleştirel düşünme becerisi önemli bir bakış açısı sağlayabilir. "Bir bak, dur bir daha bak", "aklını kullan”, "iyi düşün”, oku" gibi ifadelerde, eleştirel düşünmeyi teşvik eden uyarılar vardır. Eğer düşünmezsen, kavrayıcı bir bakışla bakmazsan, okumazsan anlayamazsın; o zaman karşına çıkan hemen her söze inanır, hemen her güç karşısında itaat durumuna geçersin. İnanma, nasıl inanılmasının yanında nasıl inanılmaması gerektiğini de içerir. Eleştirel düşünme tutumlarının eğitim alanındaki öncü isimlerinden Matthew Lipman, inanç konusunda eleştirel düşünceyi dışarıda tutar; "İnanmak eleştirel düşüncenin bir parçası değildir; varsayım, hipotez, sonuca gitme/karar verme, açıklama gibi süreçleri yoktur. $\mathrm{O}$ psikolojik bir durumdur ve bundan daha ilerisinin iddia edilmesine izin vermez" der (Lipman, 2003, s. 65). Bakıldığında bu yargının kısmen doğru olduğu görülebilir: Evet, dinlerin eleştirilemez temel akideleri vardır. Doğru olmayan yönü ise şudur: Din ve din kültürü ayrımında, inanç, kültürün ürettiği yönüyle, yorum ve açıklamalarıyla, eleştirel düşünceye sonuna kadar açıktır; din içindeki farklı yönelimler, ekoller, yollar, anlayışlar eleştirinin bir ürünüdür. Din pratik bir boyut kazanabilmek için yoruma ihtiyaç duyar. Burada eleştiri, "nas"1 eleştirme değil, üretilen yorum ve anlayışı eleştirmeye yöneliktir. Eleştirel bakış, her bir bireyin sahip olması gereken önemli bir özellik olarak inanç konusu olanı ve olmayanı birbirinden ayırmak suretiyle düşüncenin ve inancın "sağlık durumu"nu oluşturur. Eleştirel bakış olmazsa, inanç tutumları giderek hurafeleşmeye, katılaşma ve hoşgörüsüzlüğe doğru evrilir. Ve bu çoğu kez, daha iyi dindar olma adına yapılır. Din eğitiminde şu soru önemlidir: Tanrı benden gerçekten ne istemiş olabilir?

Gerçeği bulması için Tanrı'nın insana verdiği iki araç vardır: akıl ve vahiy. Din bu ikisini içerir. Bu ikisi yoksa din de olmaz. Din aklı yok etmeyi değil onu en güzel ve en etkin şekilde kullanmayı öngörür. Teslim olmanın anlamı, ancak teslim olmamak ve bütün ayartıcılar karşısında diri kalabilmekle mümkündür. Rousseau bunu içinde bulunduğu kültürün koşulları açısından şu şekilde yorumlar: “Öyleyse içtenlikle gerçeği mi arıyoruz? Hiçbir şeyi babaların, papazların otoritesine bırakmayalım, dünyaya gelişimizden başlayarak onların bize öğretmiş oldukları her şeyi vicdanın ve aklın incelemesine sunalım. Bana boş yere, "Aklını teslim et” diye bağıracaklardır. Beni aldatmak isteyenler de böyle söyleyebilir.

111

Çocuk ve Medeniyet 2021/2 Aklımı teslim etmem için nedenler bulunmalıdır. [...] Benim taptığım Tanrı karanlıklar, belirsizlikler içinde yüzen bir Tanrı değildir; o, bana bir anlama gücü verip de onu kullanmamı yasaklamadı; bana aklına boyun eğdir demek, bu aklın yaratıcısına hakaret etmek demektir" (Rousseau, 2014, s. 417-422). 


\subsection{Bireysel Otonomi}

Yaratılış, insanın otonom olacağı şekildedir; bu aynı zamanda birey olmanın, tekliğin de bir gereğidir. Tanrı isteseydi, yalnız kendi komutları ile kendi istediği şekilde hareket eden, yalnız iyiliğe ayarlı bir tür yaratabilirdi. Ama bu tür o zaman insan, eylemi de iyilik olmazdı; başka bir şey olurdu. İnsan olmanın anlamı, onun otonomisinde, seçme, karar verme ve isteme yetisinde, başka deyişle ihtiyarında ortaya çıkar. Tanrı kendi sıfatlarıyla mücehhez bir insan yaratmış, böyle bir varlık yaratmayı dilemiştir. "Allah, Âdemi kendi biçiminde (suretinde) yarattı” hadisi hatırlanabilir. Bazı felsefelerin de işaret ettiği üzere insanın en yüksek olgunluk derecesi ve yeryüzündeki varoluşunun amacı bu hedefe yaklaşmasıyla gerçekleşir (Ibn Tufeyl, 1985, s. 57-Rousseau, 2014, s. 392).

Din eğitimi belirli bir cehalet ve korku duygusu üzerinde temellenmez; cehaletin ve korkunun köleleştirdiği insanlar, dinin hedeflediği insan tipini oluşturmaz. Din, aydın, özgür ve özerk insan tipini amaçlar; bu insan tipi eğitimin de amacıdır. Din eğitimi, bireyin otonomisini yok etmeyi değil, aksine onu bir bütün olarak kurmayı ve güçlendirmeyi, sonuçta otonom bireyi ortaya çıkarabilmeyi amaçlar. Kendi seçimini yapabilen; kendisi, çevresi ve giderek tüm insanlık adına sorumluluk duyabilen, belirli değerler çerçevesinde yaşayan, kendi değerlerini üretebilen bir insan tipi, din eğitiminin en önemi hedefidir. Bu insan tipinin özelliği, sosyal-fiziksel çevre ve de kendisi ile olan ilişki ve iletişimini aşkın bir varlıkla iletişim hâlinde sürdürebilmesidir.

\subsection{Umut Söylemi}

İnancın içinde varoluşsal bir "bağlanma" durumu söz konusudur. Bu bağlanma, korkuya değil, sevgiye, güvene ve umuda bağlanmadır. Korku benden ne olduğunu anlamamı değil yalnız itaat ve teslimiyet ister. Korku, gönlün ve akılın tutumu değildir.

Din eğitimi temelini korku ve cehalette bulmaz. Cehalet bir körlük ve katılık durumudur. Dinî duyguya en çok zarar veren odur. Din eğitimi insanı köleleştirmez, aksine ona kendi potansiyelini ve özgürlüğünü tanıtır. Din eğitimi, insanlığa, ölüm ve fanilik karşısında umut ışığı yakar, sonsuzluk duygusu verir. İnancın otantikliğini, sahihliğini koruyabilmek gerekir. Din bir niyettir, saflık ve samimiyettir. Din eğitimi bir günah hesaplaması, hele hele başkalarının günahının hesabını tutma eğitimi değildir. İnsanı kendisiyle, kendi içtenliği ve varoluşsal saflığı ile karşılaştıran bir eğitimdir. Din eğitimi yaşama güç ve umudunu kıran değil, aksine bu umudu aşılayan 
ve güçlendiren bir eğitimdir. Hayattan soğutan ve koparan değil, hayatı vaat eden bir eğitimdir.

Şu bir gerçek ki, insanların, hayal gücünün acımasız bir Tanrı fikri üzerinde odaklanması, korku ve itaati kolaylaştırırken dindarlığı da oldukça zor ve kasvetli hâle getirir. Bu durumda Tanrı fikri, genel olarak sevgi ve umutla değil de korku ve endişe ile karşılanır. Bilgi, düşünce, anlayış, sevgi ve umut gibi duygusal ve zihinsel tutumların eksik olduğu inanma tutumlarında endişe ve korku hâkim olur. Oysa umut, dinî inanışlarda ontolojik bir derinliğe sahip olur. Dinin en çok yaslandığı ve insanlara vaat ettiği duygu, umuttur. Umut, Tanrı inancı ve tasavvuru ile birlikte doğar ve yaşar; korku endişe gibi ruh hâllerinin dışında bireyin Tanrı ile ilişkisi konusunda çok önemli bir kanal oluşturur. İnsanın en katı varoluş gerçekliğini oluşturan ölüm bile bir "vatana dönüş" olarak algılanır. O'na döneceksek, o zaman Varlık'a döneceğiz demektir. Varlık'a dönüş, kesin umuttur.

\subsection{Ruh Ve Beden, Dünya ve Öte-Dünya İkilemi}

Dinsel söylemlerde sıklıkla oluşturulan ikilemlerden biri "ruh" ve "beden" ve "dünya" ve "öte-dünya" ayrımıdır. Ruh ve beden, dünya ve öte-dünya ayrımı, hemen her dinin özünde bulunan bir dualitedir. Hıristiyanlıkta, "iki efendiye birden hizmet edilmez" (Luka, 16), ilkesinden hareketle, beden ve ruh arasından bir çatlak oluşturulmuştur. "Ya ruh, ya beden" ikileminde, ruh yüceltilmiş, beden aşağılanmış, karanlık ve çirkin görülmüştür. Russell, ortaçağın mistik karakterini yansıtmak için şu tür bir ifade kullanır:

"Bedenin ve giysilerin temizliği ruhun pisliği/sefaleti olarak görülürdü, bite Tanrı'nın incisi gözüyle bakılırdı" (Russell, 1983: 37). Beden şımartıldığında ruh bundan eziyet görecek ve işı̆̆ı kesilecektir. İslam kültüründe "nefs" kavramı çerçevesinde ortaya çıkan benzer bir yaklaşım söz konusudur. Derin anlamına karşın Ahmet Yesevî̀nin, "yere girme" metaforu, yine aynı şekilde Has Hacib'in “Odgurmuş” tipiyle "nefs terbiyesi”ni nasıl anladıkları hatırlanabilir (Ahmet Yesevî, 2015, s. 63-86, Has Hacib, 1958, s. 362-365). Ruh ve beden arasında oluşturulan derin çatlak aynı şekilde dünya ve ötedünya arasında da ortaya çıkar. Şöyle düşünülür: Zaten beden bu "aşağı" ve "karanlık" dünyanın bir parçasıdır. Bu dünya öyle karanlıktır ki, neredeyse manevi âlemin ışığı kesilmiş gibidir. Yapılması gereken şey, bellidir: $\mathbf{O}$ da maddenin karanlık ve çirkinliğinden sıyrılmaktır. Ruhsal yücelik bu şekilde sağlanabilir ve sonsuzluğun kapısına güvenli bir şekilde böyle varılabilir.

Çocuk ve Medeniyet 2021/2
Aslına bakılırsa insanın kesin ve sabit bir yeri yoktur. $O$, her an seyir hâlindedir. Eğer bir yeri olacaksa bu yeri insanın kendisi belirleyecektir. $\mathrm{Bu}$ onun manevi ve en temel ödevdir. Bu konuda şu söylenebilir: Esas olan, 
bedenin ve dünyanın manevi ışığın kesildiği karanlık ve aşağılık bir varlık alanı olarak görülmesi değil, insandaki ahlâk duygusunun geliştirilmesidir. Bedenin ve dünyanın aşağılanması dindarca bir tavır olmayacaktır. Zira bu beden ve içinde yaşadığım bu dünya benim kendi seçimim değildir. Bedenimi kötülemenin, onu karanlık ve aşağılık bir alan olarak görmenin insanca bir anlamı yoktur. Dünyadaki varlığım ancak bir beden içinde ve bir bedenle birlikte vardır. Din eğitiminin çocuğa verebileceği en iyi mesajlardan biri bedenini sevmesi, onu en iyi şekilde koruması, ona bir ahlâk elbisesi giydirebilmesidir. Zira bedenim yok olduğunda, dünyasal varlığım da ortadan kalkacak, "ben" dediğim bu şey de dağılmaya uğrayacaktır.

Yine bunun gibi dünyayı kötü ve aşağılık bir yer olarak gördügümüzde din ve dindarlık adına, insanlık ve medeniyet adına iyi bir şey yapmış olmayız. Sonuçta orayı da Tanrı yaratmış, bu beden içinde bizi orya koymuştur. Bu düzeni küçümsemek, hor hakir görmek, tanrısal iradeyi de küçümsemek, olacaktır. Bu bedenle bu dünyada en iyi şekilde yaşayarak bu kusursuz iradeyi anlayabilmek gerekir. Bedeni ile olduğu gibi dünya ile ilişkisi de insanın dindarlığının önemli bir parçasını oluşturur. Bu ilişkinin içeriğinde dünyayı imar etmekten orada insanî ve ahlâkî bir düzen oluşturmaya kadar geniş yelpazede bir varoluş alanı yer alır. Bu anlamda yeryüzüne bağlanma onu aşağılama şeklinde değil, değerle yaşama, onu kavrama ve bilme şeklinde gerçekleşir. Bu sayede tabiatta çözdüğüm her düğüm sayesinde aklım tanrısal irade, Yaratıcı Kudret ve hikmetle yeniden buluşur, "Tanrı zihinsel, akıl yolu ile anlaşılmaya uygun (intellectual) bir dünya yaratıyor.” diyor (Locke, 1922, s. 248). Tabiatın sırlarını anlarken, kendi idrak sınırlarım içinde yaratıcı iradeyi de anlarım. Yeryüzünde erdemli ve adaletli bir düzen oluşturmak kadar dünyadaki harmoni ve geometriyi okuyup anlayabilmek de tanrısal iradeye yaklaşım yollarından biri olacaktır.

\subsection{Hayatın Anlamı Sorunu}

İnsan sadece yaşamak istemez, aynı zamanda yaşadığı hayatı sıkıntı içinde de geçse anlamlı hissetmek ister. Hayatı anlamlı hissetmek yaşanan zorlukları, yapılan mücadele ve çalışmaları değerli kılar. Anlam sorunu, bireyin inançları, sahip olduğu değerler ve bir bütün olarak onun hayat anlayışı ile ilgilidir. Hayatın ve dünyadaki varlığımın anlamı ne olmalı, gibi bir soru ister istemez her bireyin hayatında yer alır ve bu sorular bireyi ister istemez Tanıı inancı ile karşı karşıya getirir. Ayer gibi bazı filozoflar bu soruyu metafizik içeriğinden dolayı anlamlı bir soru olarak görmezler ve onun yerine "nasıl yaşamalıyım" sorusunu önerirler (bkz. Ayer, s.119- 
132); bununla birlikte hayatın anlamı sorunu, yine de insanın kendisinden kaçınamayacağı bir sorundur.

Din eğitiminde hayatımın anlamı ile ilgili soruyla da karşılaşırım. İnanırken bu sonsuz zaman ve evren içinde, şimdi ve burada bulunan, nefes alan, soru soran ve kaygı duyan bu benlik için bir ışık, bir gerekçe ve umut arıyorum. İnanmanın esas olarak böyle varoluşsal bir boyutu vardır. İnanırken, kendi kökenimizle, kendimizle, kendi varoluşsal gerçekliğimizle, varlığımızın gerekçesi ve anlamıyla bağlantı kurmaya çalışırız. Din eğitiminin bu bağlamda insan hayatında önemli bir yeri vardır.

\subsection{Halkın Din Eğitimi}

Toplumun en eğitici kurumlarından biri, aile ve okulların yanında, mabetlerdir. Özellikle dinî mekânlara ilginin yoğun olduğu, toplu hâlde ibadet etmenin değerine ve iyiliğine inanan toplumlarda bir kültür mekânı olarak mabedin önemli yeri vardır. İnsanlar burada normal hayatta hissedemedikleri manevi duygular edinirler; sergilenmesi gereken davranışlar, gösterilmesi gereken tavırlar konusunda bilgi alırlar. Din adamları konuşmaları, davranışları, açıklamaları ile halkı kolaylıkla etkileyebilecek kişiler olarak haftada en az bir kere halka hitap etme imkânı bulurlar. Bu hitabette, "sen dili" kullanmadan, horlamadan, ötekileştirmeden, aydınlatıcı bir söylemle olumlu duygular oluşturacak şekilde pedagojik bir din dilinin kullanılması önemlidir. Din eğitimi, merhameti, şefkati, bağışlamayı esas alır. Tanrı'nın sonsuz kudreti, ilmi ve rahmeti karşısında katılığı değil hoşgörüyü, cehaleti değil ilmi ve bilgiyi, korkuyu değil umudu esas alır. Bunun sonucunda tahammül ve hoşgörü eşiği düşük, gergin, takıntılı, iletişim kapıları kapalı, kendi içine dönük ayrışmış bir toplum manzarası değil, ölçülü, saygılı ve hoşgörülü otonom bireylerin erdemli toplumu ortaya çıkar. Şu çok açıtır: Din adamları rahmet, hoşgörü, bağışlama, sevgi kapılarını açtıklarında, insanların yüzlerinin güldüğü, daha olumlu tutumlar sergiledikleri, daha umutlu oldukları görülebilir. Dinî mesaj, insanların hayata olan bağlılıklarını sarsacak ve "ölüm-sevicilik" davranışları oluşturacak şekilde olmamalıdır. Evet, bir gün herkes ölecek ve dünya hayatı sonsuza değin bitecektir. Ölüm ve ölümün şiddeti söylemi üzerine bir din ve din eğitimi, bir ahlâk ve erdem anlayışı inşa etmeye çalışmak, insanî ve ahlâkî, dinî ve pedagojik bir yaklaşım olmayacaktır.

Halkı eğitecek din adamlarının sadece belirli dinî bilgilerle donanmış olmaları yetmez, kaynaklara ulaşabilme konusunda gerekli olan filolojik yeterlilik yanında temel metinleri zengin bir bakış açısıyla ele alabilmek 
için tarih, felsefe, sosyoloji, psikoloji, antropoloji, edebiyat, sanat, dinler tarihi gibi geniş bir alanda insanlık değerlerini özümsemiş olmaları, eğitici ve terbiye edici bir dil kullanabilmeleri de gerekir. İbadet mekânları, özellikle modern hayatın ağır baskı ve stresinden bunalmış çağdaş insan için rahatlayıp nefes alabilecekleri, kendilerini ve yaşadıkları hayatı sorgulayabilecekleri ender dinginlik alanlarından biridir. İbadet mekânlarında insanlara halka hitap eden din adamlarının aydın, kültürlü, donanımlı, yetenekli olmaları, dinî bilgiler yanında yüksek bilim ve sanatlara vakıf olmaları, bunun yanında pedagojik bir anlayışa ve azami nezaket diline sahip olmaları da gerekir. Aksi hâlde vermeye çalıştıkları eğitim, eğitim ve terbiye karşıtı bir tutuma dönüşebilecektir.

\subsection{Zorunlu mu, Seçmeli mi?}

Son olarak her zaman her yerde tartışılan bir konuya değinmekte fayda olabilir: Din dersi olmalı mı olmamalı mı, seçmeli mi yoksa zorunlu mu olmalı?

Bu konudaki tartışmalara kısaca değinecek olursak şunları söyleyebiliriz: Düşünce tarihinde din eğitimi ile ilgili birbirinden farklı görüşler yer almaktadır. Sözgelimi Rousseau gibi bazı filozoflar, çocukluk yaşının din eğitimi için, bu yönde bir tercih yapabilmek için uygun olmadığını, bunun yerine zamanı gelince, söz gelimi 15'li yaşlardan sonra, buna bizzat çocuğun kendisinin karar vermesinin doğru olacağını söyler (Rousseau, 2014, s. 190). Yusuf Has Hacib gibi, Kınalızâde gibi, Locke gibi bazı filozoflar ise -bunlar arasında Nurettin Topçu da vardır- çocuğun zaman geçirmeden bu eğitimi alması gerektiğini düşünürler. Locke'a göre "Erdemin temeli olarak çocuklara çok erken yaşta üstün varlık olarak Tanrı düşüncesinin yerleştirilmesi gerekmektedir. Her şeyi yazan ve yapan ve tüm şeyleri kendisinden aldığımız, bizi seven ve bize her şeyi veren Tanrı fikri çocukların zihnine yerleştirilmeli, bu üstün varlığı sevmesi ve O'na saygı duyması öğretilmelidir" (Locke, 2004, s. 123-124). Bu eğitim, sanat ve edebiyat, tarih ve felsefe, din ve ahlâk gibi kültür dersleriyle birlikte bir değer ve şahsiyet eğitimi olması anlamında diğer bütün bilimsel ve teknik eğitimler için temel oluşturacaktır. Bu nedenle Topçu, bu eğitimin, şahsiyet yapıcı bir eğitim olarak teknik eğitimden daha önce verilmesini ister ve "Bize teknik okuldan daha çok idealist insan yetiştiren mektepler lazımdır." der (Topçu, 1998, s. 176).

Çocuk ve Medeniyet 2021/2
Yukarıda verilen iki tür din eğitimi ayrımından hareketle söylersek: Din eğitimi, felsefî, sosyolojik, tarihsel, antropolojik içerimleri olan, insanın yeryüzündeki derin ruhsal tecrübesine ışık tutacak bir ders anlamında 
okulun program türüne göre zorunlu veya seçmeli bir ders olarak okutulabilir. Belirli bir dinin içeriğinin, akidelerinin, inanç kurallarının öğretilmesi anlamında bir din eğitiminin seçmeli olarak okutulması, dinsel tolerans ve dinlerin insan iradesine yaptıkları vurguya uygun olacaktır. Din eğitiminin temeli, bireyin isteğine, talebine, ihtiyacına dayanmalıdır. İstemediği bir dersi kişiye vermeye çalışmak, pedagojik ve dinî bir yaklaşım olmayacaktır. Asıl olan kandan, sinirden, çeşitli uzuvlardan bir insan ortaya çıkarabilmek, organizmayı insan hâline getirebilmektir.

\section{Sonuç}

Din, ibadetleri ve ortaya koyduğu davranış tarzları, insanlara verdiği değerle her ne kadar somut bir görünümde olsa da, aslında bütün bu somut göstergelerin gerisinde somut olmayan bir temele, bir tanrı, peygamber, sonsuz ve ölümsüz bir ruh inancına dayanır. Bu nedenle dinî duygunun olumlu kavramlarla birlikte kurulması, kişi, toplum ve medeniyet açısından büyük bir sevinç, umut ve güç kaynağı olacaktır. Bizi yaratan, hayat ve rızık veren, sonsuzluk ve umut veren bir Tanrı imajı, sadece bireyler açısından değil, toplum, devlet ve medeniyetler açısından da önem taşıyacaktır. Soyut bir temele dayanan dinî inanış, bu şekilde insan dünyasında tecelli ettiğinde, kendi doğasına uygun bir noktadan hareket etmiş olur. Tanrı tasavvurum bende pozitif duygular ve yaşama tutumları oluşturacak, yer kabuğuna tutunma gücümü ve direncimi artıracak, yaşama sevinç ve umudumu destekleyecek şekilde olmalıdır. Korkutan, sindiren, sarsan, katılaştıran, evhamlarla donatan bir din ve Tanrı fikri, yanlış bir din eğitiminin eseri olabilir. "Ben sizin zannınız üzereyim”, kutsî hadisi, O’nu en iyi şekilde tasavvur edebilmemiz için bize güçlü gerekçeler sunar. Aksi bir tutum, onun yüceliğine, iyiliğine, iradesine ve merhametine uygun düşmeyecektir.

Şu hâlde din eğitiminde asıl olan, Tanrı hakkında doğru, uygun ve makul bir tasavvur oluşturabilmektir. Bu tasavvur çerçevesinde organize edilen din eğitimi: (1) Hayatın boş ve anlamsız olduğu yönünde bir karamsarlık oluşturmaz. (2) Dünyayı kötülemez, küçümsemez. (3) Bedeni kötülemez, küçümsemez. (4) Hayatın güzellik ve nimetlerini kötülemez, küçümsemez; bütün bunları en ahlâkî ve en insanî şekilde nasıl kullanabilirim, sorusuna cevap arar. (5) İnancın ilâhî inayet ile olan bağını kurar, diğer din ve inançlara karşı nefret söylemi oluşturmaz. (6) Zorlaştırıcı değil kolaylaştırıcıdır. (7) Kişiyi kendi hayatının öznesi olarak aktif bir konumda tutar. (8) Toplumdan soyutlamaz, bir arada yaşama duygusu kazandırır. (14) Bir cinsin aşağılanması veya yok sayılmasına neden olacak şekilde cinsiyet ayrımcılığına gitmez. (9) Tanrı'yı en yüce ve en kuşatıcı varlık 
olarak verdikten sonra O'nu sürekli insanlarla uğraşan, hoşgörüsüz, sinirli, tahammülsüz, insanların açığını kollayan bir varlık olarak göstermez.

(10) Özgürlük duygusunu, sorumluluk duygusuyla birlikte bir bilinç ve otonomi oluşturacak şekilde en geniş sınırlarıyla verir. Gereksiz kısıtlama ve yasaklamalara gitmez. (11) Merakı, bilmeyi ve anlamayı teşvik eder. (12) İbadeti sadece belirli dinî vecibelerle sınırlı tutulmaz; iyi ve erdemli yaşamanın baştan sona ibadet olduğu duygusunu kazandırır. (13) Korku ve kaygıdan değil sevgi ve umuttan hareket eder. (14) Merhamet duygusunu öne çıkarır.

Görüleceği üzere din eğitimi, din ve din kültürüne ilişkin bilgilerin yanında, kişisel otonomiyi destekleyecek ve güçlendirecek şekilde, hayata yönelik ilgi ve merakın, tutum ve davranışların felsefî ve bilimsel düzeyde ifade bulduğu temel bir eğitim alanıdır. $\mathrm{O}$, yalnız belirli akidelerin öğretildiği bir ders olarak görüldüğünde tam olarak anlaşılmış sayılmaz. Din eğitimi aslında bütün bunların anlamı ile ilgili bir derstir; bu nedenle dinî olmaktan çok felsefî bir bakış açısına ihtiyaç duyar. Bu eğitim biçiminde insanın Tanrı'ya olan bağlılığı, aynı zamanda insanın insana ve insanın tüm varlığa bağlılığı olarak yeniden kurulur, bu yönde bir ruh, zihin ve gönül terbiyesi oluşur.

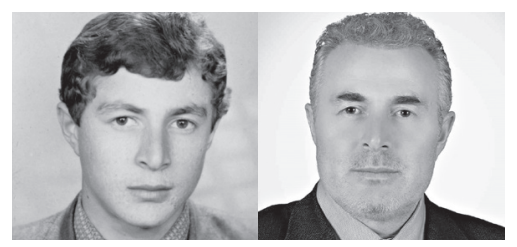

Vefa Tașdelen

\section{Kaynakça}

Ahmet Yesevî (2015). Divan-ı Hikmet, Haz. Hayati Bice. Ankara: Diyanet Vakfı yayınları.

Augusitine (1996). The Confessions of Saint Augustine. New Kensington: Whitaker House.

Ayer, A. J. The Claims of Philosophy. The Meaning of Life'da (Ed. E.D. Klemke). Oxford University Press, London, 2000.

Descartes, R. (1997). Metafizik Düșünceler. Cev. Mehmet Karasan. İstanbul: Milli Eḡitim Basımevi. Dostoyevski, F. (1984). Ecinniler 1 (Cev.: İ. Yergüz - E. Özden). İstanbul: Sosyal yayınlar. Gazâlî (1996). İslam Ahlâkı (Cev.: Akif Nuri). İstanbul: Sinan Yayınları. 
İbn Sina (1997). Risâle-i Hayy İbn Yakzân (Çev.: D. Örs (Sembolik Hikâyeler içinde). İstanbul: İnsan Yayınları.

İbn Tufeyl (1985). Ruhun Uyanıșı Ya da Hayy İbn Yakzan'ın Olaḡanüstü Serüveni (Çev.: Babanzade Reșit). İstanbul: İnsan Yayınları.

Jaspers, K. (1986). Felsefe Nedir? (Cev.: I. Zeki Eyüboḡlu). İstanbul: Say Yayınları.

Kant, I. (1908). Educational Theory Of Immanuel Kant. Tr. E.F. Buchner. Philadelphia-London: J.B. Lippincoat Company.

Kınalızâde Ali Efendi (Tarihsiz). Ahlâk-ı Alâî. İstanbul: Tercüman Yayınları.

Lipman, M. (2003). Thinking in Education. Cambridge: Cambridge University Press.

Locke, J. (1922). The Educatıonal Writings Of John Locke. Cambridge: Cambridge University Press.

Locke, J. (2004). Eḡitim Üzerine (Cev.: A. Uḡur). Ankara: Yeryüzü Yayınevi.

Platon (1992). Devlet (Cev.: S. Eyüboğlu - M. Ali Cimcoz). İstanbul: Remzi Kitabevi.

Rousseau, J.J. (2014). Emile (Cev.:Y. Avunç). İstanbul: İș Bankası Yayınları.

Russell, B. (1999). Eğitim Üzerine (Cev.: N. Bezer). İstanbul: Say Yayınları.

Russell, B. (1983). Evlilik ve Ahlâk (Cev.: V. Eranus). İstanbul: Say Yayınları.

Topçu, N. (1998). Türkiye'nin Maarif Davası. İstanbul: Dergah Yayınları.

Yusuf Has Hacib (1959). Kutadgu Bilig II. (Haz. Reșit Rahmeti Arat). Ankara: Türk Tarih Kurumu Basımevi. 


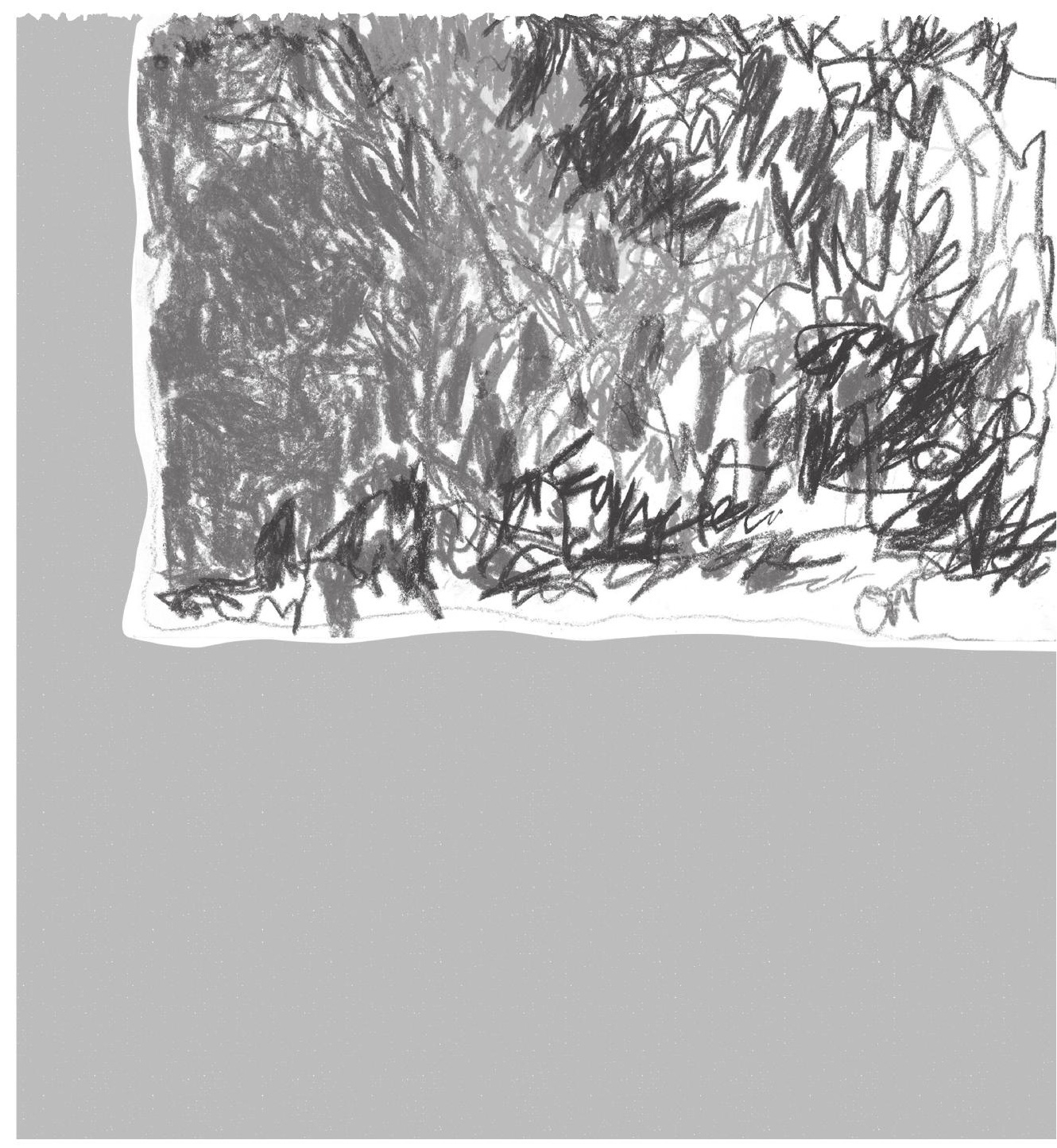

